JUSTITIA : Jurnal Ilmu Hukum dan Humaniora

issn cetak :2354-9033 || issn online :2579-9398 || Vol. 1 No. 2 Tahun 2019

http://jurnal.um-tapsel.ac.id/index.php/justitia

\title{
PENYELESAIAN SENGKETA PROSES PEMILU OLEH BAWASLU, TANTANGAN DAN MASA DEPAN
}

\author{
Aermadepa \\ Fakultas Hukum UMMY SOLOK \\ Korespondensi: advokat.aermadepa@gmail.com
}

\begin{abstract}
Abstrak
Tulisan ini bertujuan untuk membahas penyelesaian sengketa proses Pemilu oleh Badan Pengawas Pemilu (Bawaslu), sekaligus tantangan dan bagaimana sengketa proses Pemilu ini sebaiknya kedepan. UndangUndang Nomor 7 Tahun 2017, pasal 95 huruf d memberikan wewenang kepada Bawaslu untuk menerima, memeriksa, melakukan mediasi dan adjudikasi serta memutus penyelesaian sengketa pemilu. Artinya berdasarkan Undang-Undang Nomor 7 Tahun 2017 dalam melakukan penyelesaian sengketa proses Pemilu, Bawaslu diberikan tambahan kewenangan untuk melakukan mediasi dan adjudikasi. Penyelesaian sengketa bagi Bawaslu adalah mahkota yang keberadaannya dinantikan oleh masyarakat dalam menyelesaikan sengketa yang kerap terjadi saat tahapan Pemilu. Untuk menjawab tantangan dan agar sampai ke tujuan suatu saat nanti Bawaslu menjadi Pengadilan Pemilu, maka Bawaslu harus segera menyiapkan infrastruktur untuk menjaga efektifitas penyelesaian sengketa serta penguatan kapasitas Bawaslu di daerah, terutama Bawaslu Kabupaten/Kota untuk lebih giat melatih kemampuan serta mental mereka yang masih rendah dalam menyelesaikan sengketa pemilu.
\end{abstract}

Kata-kata Kunci: Penyelesaian Sengketa; Pemilu; dan Bawaslu

\section{Abstract}

This paper aims to discuss dispute resolution of Election process by Election Supervisory Agency (Bawaslu), as well as challenges and how to dispute the election process in the future. Act Number 7 of 2017, Article 95 letter $d$ authorized the Election Supervisory Agency to receive, examine, mediate and adjudicate and decide on the resolution of election disputes. This means that based on Act Number 7 of 2017 in resolving disputes over the election process, Bawaslu is given additional authority to conduct mediation and adjudication. Settlement of disputes by Bawaslu is a crown whose existence is awaited by the community in resolving disputes that often occur during the election stage. To answer the challenge and to get to the destination someday Bawaslu becomes the Election Court, then Bawaslu must immediately build facilities to maintain the effectiveness and capacity of Regional Bawaslu, especially District / City Bawaslu to be 
more active in training their abilities and their mentaly, which are still low in resolving election disputes.

Key words: Dispute resolution, General election, Election Supervisory Agency.

\section{PENDAHULUAN}

Tulisan ini berusaha menggambarkan penyelesaian sengketa proses Pemilu oleh Bawaslu, sekaligus tantangan dan bagaimana sengketa proses Pemilu ini sebaiknya kedepan. Karena sebagaimana kita ketahui bahwa sengketa proses ini baru mulai digawangi oleh Badan Pengawas Pemilu (Bawaslu) adalah semenjak Pemilu 2014 yang lalu, dimana saat itu sengketa peoses Pemilu hanya diselesaikan ditingkat Bawaslu dan Bawaslu Provinsi. Namun dengan diberlakukannya Undang-Undang Nomor 7 Tahun 2017 tentang Pemilhan Umum (Pemilu) yang juga mengamanatkan penyelesaian sengketa proses Pemilu ini kepada Bawaslu Kabupaten/Kota, sekaligus memperkuat keberadaan Bawaslu Kabupaten/Kota menjadi lembaga permanen.

Undang-Undang Dasar Negara Republik Indonesia Tahun 1945 telah meletakkan dasar pemerintahan demokratis dengan mengamanatkan Pemilu berkala. Hal ini diatur dalam UUD NRI 1945 BAB VIIB Pasal 22 E dengan judul "PEMILU". Adapun bunyi Pasal 22 E, yaitu:

(1) Pemilihan umum dilaksanakan secara langsung, umum, bebas, rahasia, jujur, dan adil setiap lima tahun sekali.

(2) Pemilihan umum diselenggarakan untuk memilih anggota Dewan Perwakilan Rakyat, Dewan Perwakilan Daerah, Presiden dan Wakil Presiden dan Dewan Perwakilan Rakyat Daerah

(3) Peserta pemilihan umum untuk memilih anggota Dewan Perwakilan Rakyat daerah adalah partai politik.

(4) Peserta pemilihan umum untuk memilih anggota Dewan Perwakilan Daerah adalah perseorangan.

(5) Pemilihan umumdiselenggarakan oleh suatu komisi pemilu yang bersifat nasional, tetap, dan mandiri.

Selanjutnya Pemilu lahir dari konsepsi dan gagasan besar Demokrasi yang merujuk pada John Locke dan Rousseau, yaitu keterjaminan kebebasan, keadilan dan kesetaraan bagi individu dalam segala bidang. Pemilu sering disebut sebagai ajang pesta demokrasi rakyat yang menjadi cerminan ikut andilnya rakyat dalam menentukan pemimpin dan arah perkembangan bangsa. Namun dalam perkembangannya pemilu di Indonesia masih banyak kekurangan dan menjadi pekerjaan rumah yang perlu diperbaiki bersama oleh seluruh elemen bangsa.

Pemilu penting untuk dilakukan mengingat Indonesia adalah negara demokrasi, sebagaimana sudah dikemukakan oleh Sri Soemantri M, bahwa syarat demokrasi sebagaimana yang 
diajukan oleh International Commission of Jurist di Bangkok tahun 1965 yaitu(Sri Soemantri M,1998: 43)

1. adanya proteksi konstitusional

2. adanya kekuasaan peradilan yang bebas dan tidak memihak

3. adanya pemilihan umum yang bebas

4. adanya kebebasan untuk menyatakan pendapat dan berserikat

5. adanya tugas-tugas oposisi

6. adanya pendidikan civis

Sementara menurut Ramlan SurbaktiPemilu adalah sebagai sebuah instrument dirumuskan sebagai:(1)mekanisme pendelegasian sebagian kedaulatan dari rakyat kepada pesertaPemilu dan/atau calon anggotaDPR,DPD,DPRD,Presiden/WakilPresiden,danKepala Daerah/WakilKepalaDaerahuntukmembuatdanmelaksanakan keputusanpolitik sesuai dengan kehendak rakyat;(2)mekanisme perubahan politik mengenai pola dan arah kebijakan publik, dan/atau mengenai sirkulasi elit, secara periodik dan tertib; (3)mekanismepemindahan berbagai macam perbedaandan pertentangankepentingandarimasyarakat kedalam lembaga legislatif dan eksekutif untuk dibahas dan diputuskan secaraterbuka dan beradab(Ramlan Surbakti, dkk, 2008:32).

Pemilu merupakan salah satu sarana bagi rakyat untuk ikut aktif dalam proses politik, sehingga akan mencerminkan adanya prinsip dasar kehidupan kenegaraan yang demokratis(Dahlan Thaib,1993:94). Sedangkan menurut Jimly Asshiddiqie, salah satu tujuan Pemilu adalah untuk melaksanakan kedaulatan rakyat di lembaga perwakilan(Jimly Asshiddiqie,1994:9). Sehingga mekanisme pengisian jabatan wakil-wakil rakyat seperti, Dewan Perwakilan Rakyat (DPR), Dewan Perwakilan Daerah (DPD), dan Dewan Perwakilan Rakyat Daerah (DPRD) dilakukan melalui keterlibatan rakyat secara langsung dalam suatu proses Pemilu.

Perubahan model sistem pemilu dari pemilu ke pemilu berikutnya juga selalu menjadi fenomena tersendiri di Indonesia. Demikian juga perubahan terhadap penyelenggara Pemilu itu sendiri. Dimana diawali dengan Perubahan Undang-Undang Dasar Negara Republik Indonesia Tahun 1945 dalam Perubahan ketiga Pasal 22E ayat 5 menyebutkan bahwa Pemilihan umum diselenggarakan oleh komisi pemilihan umum yang bersifat nasional, tetap dan mandiri.

Meskipun Undang Undang Dasar hanya menyebut Komisi Pemilihan Umum dalam Pasal 22E ayat 5, namun ini tidaklah berarti KPU sebagai satu-satunya penyelenggara Pemilu. Karena kemudian berturut-turut dibentuk Badan Pengawas Pemilu (Bawaslu) dan Dewan Kehormatan Penyelenggara Pemilu (DKPP).

Sebagai lembaga baru keberadaan lembaga penyelenggara Pemilu, terutama Bawaslu dan jajaran sampai ke Bawaslu Kabupaten/Kota tentu masih harus berbenah untuk 
membuktikan pentingnya eksistensi lembaga dimaksud. Sebagaimanana dikemukakan oleh Jimly Asshiddiqie bahwa banyak kalangan yang berpendapat bahwa fenomena munculnya lembaga-lembaga negara seperti ini banyak terjadi terutama pada negara yang berada pada fase transisi menuju demokrasi. Selain itu, pembentukan lembaga-lembaga non struktural juga didorong oleh kenyataan bahwa birokrasi di lingkungan pemerintahan dinilai tidak mampu memenuhi tuntutan kebutuhan akan pelayanan umum dengan standar mutu yang baik, efisien dan efektif. Birokrasi yang gemuk, di samping dinilai tidak efisien untuk kepentingan pelayanan umum, juga dinilai cenderung korup, tertutup dan tidak lagi mampu menampung aspirasi rakyat yang terus berkembang. Dinamika tuntutan demokrasi, hak-hak warga negara, dan tuntutan akan partisipasi terus meningkat dari waktu ke waktu(Jimly Asshiddiqie,2010:25).

Perjalanan Bawaslu sendiri menjadi penyelenggara Pemilu tidaklah seketika. Dari Pemilu ke Pemilu pembuat undang-undang sudah sepakat untuk senantiasa memperkuat peran dan fungsi lembaga pengawas Pemilu ini. Sebagaimana dikatakan oleh Didik Sukriono, bawa mengingat fungsi Bawaslu yang sangat dibutuhkan, maka Bawaslu ditetapkan sebagai penyelenggara Pemilu yang bersifat tetap dan mempunyai kewenangan mengawasi jalannya Pemilu. Hal ini sesuai dengan pendapat bahwa eksistensi lembaga pengawas Pemilu akan semakin lemah apabila tidak mempunyai kewenangan yang maksimal, sehingga berakibat pada kurang maksimalnya kinerja Bawaslu tersebut. Kelemahan-kelemahan yang dimiliki oleh Bawaslu akibat keterbatasan tugas dan kewenangan dalam mengawasi penyelenggaraan Pemilu pada akhirnya akan dapat membahayakan perjalanan demokrasi di Indonesia(Didik Sukriono,2009:11).

Maka dalam rangka penguatan peran dan fungsi Bawaslu serta untuk memperkuat legilimasi terhadap proses Pemilu di Indonesia Undang-Undang Nomor 7 Tahun 2017 memperkokoh peran Bawaslu sebagai lembaga penyelesaian sengketa proses Pemilu. Amanat mana juga diserahkan kepada Bawaslu Kabupaten Kota.

Berkaca dari pengalaman penyelesaian sengketa proses Pemilu dalam Pemilu 2014 yang lalu, yang tidak gampang. Dibuktikan dengan banyaknya kesemrautan Pemilu yang berawal dari Putusan Bawaslu dan jajarannya dalam menyelesaikan sengketa Pemilu. Apalagi Pemilu 2019 yang sangat kompleks tentu saja penyelesaian sengketa proses Pemilu-nya tidaklah gampang. Untuk itulah penulis tertarik menulis artikel ini dengan judul Penyelesaian Sengketa Proses Pemilu oleh Bawaslu, Tantangan dan Masa Depan. 


\section{PEMBAHASAN}

\section{A. Penyelesaian sengketa Proses Pemilu oleh Bawaslu}

Sengketa adalah Pertentangan atau konflik yang terjadi antara individu-individu atau kelompok-kelompok yang mempunyai hubungan atau kepentingan yang sama atas suatu objek kepemilikan, yang menimbulkan akibat hukum antara satu dengan yang lain. (Winardi,2007:1). Sedangkan menurut Takdir Rahmadi konflik atau sengketa adalah situasi dan kondisi di mana orang orang saling mengalami perselisihan yang bersifat faktual maupun perselisihan-perselisihan yang ada pada persepsi mereka saja.( Takdir Rahmadi,2011:1).

Secara umum penyelesaian sengketa bisa dilakukan melalui jalur litigasi (melalui persidangan di pengadilan). Dimana prosedur dalam jalur litigasi ini sifatnya lebih formal (very formalistic) dan sangat teknis (very technical). Jalur lain untuk penyelesaian sengketa adalah jalur non litigasi, yang lebih dikebal dengan penyelesaian sengketa alternatif atau Alternative Dispute Resolutin (ADR), yang dijelaskan dalam Pasal 1 angka (10) Undang-Undang Nomor 30 Tahun 1999 Tentang Arbitrase dan ADR, yang berbunyi : "Alternatif Penyelesaian Sengketa adalah lembaga penyelesaian sengketa atau beda pendapat melalui prosedur yang disepakati para pihak, yakni penyelesaian sengketa di luar pengadilan dengan cara konsultasi, mediasi, konsiliasi, atau penilaian ahli."

Namun penyelesaian sengketa yang dilakukan oleh Bawaslu tentulah tidak termasuk dalam jalur litigasi maunpun non litigasi. Karena penyelesaian sengketa Pemilu adalah penyelesaian sengketa khusus, yang merupakan bagian dari penengakan hukum Pemilu. Sebagaimana Standar internasional ini menjadi syarat minimal bagi kerangka hukum untuk menjamin pemilu yang demokratis yang dikemukakan oleh nternational Institute for Democracy and Electoral Assistance (International IDEA), yaitu 15 aspek pemilu demokratis,(Topo Santoso, dkk, 2006:12). yaitu penyusunan kerangka hukum; pemilihan sistem pemilu; penetapan daerah pemilihan; hak untuk memilih dan dipilih; badan penyelenggara pemilu; pendaftaran pemilih dan daftar pemilih; akses kertas suara bagi partai politik dan kandidat; kampanye pemilu yang demokratis; akses ke media dan kebebasan berekspresi; pembiayaan dan pengeluaran; pemungutan suara; penghitungan dan rekapitulasi suara; peranan wakil partai dan kandidat; pemantauan pemilu; kepatuhan terhadap hukum; dan penegakan peraturan pemilu.

Sengketa Pemilu atau perselisihan dapat dibagi menjadi dua, yaitu: (1) sengketa dalam proses pemilu (khususnya yang terjadi antar-peserta pemilu atau antarkandidat) yang selama ini ditangani panitia pengawas pemilu; dan (2) sengketa atau 
perselisihan hasil pemilu. Sesuai ketentuan UUD 1945, UU Pemilu, dan UU MK; wewenang penyelesaian perselisihan hasil pemilu berada di tangan Mahkamah Konstitusi.

Sebenarnya ada lagi sengketa yang ketiga, yang tidak diatur di dalam UU, yakni: (3) sengketa peserta atau calon yang keberatan atas penetapan KPU atau KPUD. Sejumlah masalah terjadi dalam pemilu dan pilkada terjadi sebagai akibat kekurangan aturan main yang perlu diperbaiki pada masa mendatang. Salah satu masalah yang kerap muncul adalah keputusan penyelenggara pemilu mengenai peserta pemilu dan kandidat presiden (serta kandidat kepala daerah). Gagalnya calon peserta pemilu serta bakal kandidat presiden dan kepala daerah akibat keputusan penyelenggara pemilu masih terus terjadi.(Kemitraan,2011:3).

Mengacu 15 standart Internasional pemilu demokratis diatas, kiranya poin terkahir yakni kepatuhan terhadap hukum dan penegakan peraturan pemilu belum berjalan dengan baik. Utamanya bagi peserta pemilu atau partai politik pengusung pasangan yang kalah suara dalam Pemilihan. Ujung-ujungnya Mahkamah Konstitusi menjadi benteng terakhir yang menyidangkan sengketa hasil pemilu. Pada dasarnya penegakan hukum pemilu adalah suatu mekanisme untuk menjaga hak pilih suara rakyat. Tujuannya memastikan bahwa penyelenggaraan pemilu terjadi secara jujur, adil, tidak terjadi kecurangan, manipulatif oleh peserta pemilu, sehingga menghasilkan pemimpin dengan label legitimasi kuat yang dianggap paling ideal disebuah wilayah tertentu. Dan ada dua cara yang dapat ditempuh dalam menegakkan hukum pemilu(Mohammad Dawam,2018)

Jadi penegakan hukum Pemilu merupakan suatu hal yang mutlak dilakukan untuk mencapai Pemilu yang demokratis. Dan penyelesaian sengketa Pemilu, baik sengketa proses maupun sengketa hasil Pemilu merupakan bagian dari penegakan hukum Pemilu. Hingga sudah seharusnya lah penyelesaian sengketa proses Pemilu mendapat tempat tersendiri dalam undang-undang Pemilu. Karena sebagaimana dikemukakan oleh "Kemitraan" bahwa sukses pemilu tidak hanya ditentukan dari terlaksananya pemungutan suara, tetapi juga penyelesaian sengketa yang terjadi. Masalah penyelesaian sengketa pemilu di Indonesia mulai ramai dibahas khususnya sejak Pemilu 2004.

Dari penyelenggaraan Pemilu tahun 2014 kemarin yang memperlihatkan beragam persoalan, khusus nya terhadap proses penegakkan hukum Pemilu, penanganan kasus-kasus pelanggaran maupun penyelesaian perkara-perkara perselisihan cenderung berkepanjangan dan berbelit-belit mengabaikan prinsip efisiensi dan efektivitas di dalam penegakan hukum Pemilu, padahal Pemilu menghendaki 
penyelesaian yang cepat untuk menghindari potensi hilangnya hak-hak pemilih dan peserta pemilu dan mencegah terganggunya pemerintahan.

Perubahan model sistem pemilu Indonesia dari pemilu ke pemilu berikutnya juga telah menjadi fenomena tersendiri, hal ini dikarenakan perkembangan dan situasi perpolitikan bangsa Indonesia yang juga terus berubah. Namun yang terpenting tentu saja diharapkan perubahan itu membawa Pemilu di Indonesia menjadi Pemilu yang demokratis.

Salah satu perubahan mencolok dalam menyambut Pemilu 2019 adalah Pemilu serentak yang diawali dengan Putusan Mahkamah Konstitusi No.14/PUU-XI/2013 merupakan pengujian Pasal 3 ayat (5), Pasal 12 ayat (1) dan ayat (2), Pasal 14 ayat (2), dan Pasal 112 Undang-Undang No.42 Tahun 2008 tentang Pemilihan Umum Presiden dan Wakil Presiden. Beberapa pasal tersebut mengatur bahwa ketentuan Pemilu Anggota Lembaga Perwakilan dan Pemilihan Presiden yang dilaksanakan terpisah, namun berdasar putusan Mahkamah Konstitusi ketentuan beberapa pasal tersebut dinyatakan bertentangan dengan UUD 1945 dan tidak mempunyai kekuatan hukum mengikat. Implikasi dari pembatalan tersebut adalah dilaksanakannya "Pemilihan Umum Nasional Serentak" atau Pemilu Anggota Lembaga Perwakilan dan Pemilihan Presiden dilakukan secara serentak yang dimulai pada tahun 2019 dan tahun-tahun selanjutnya.

Menurut Mahkamah Konstitusi bahwa dalam penyelenggaraan Pilpres tahun 2004 dan tahun 2009 yang dilakukan setelah Pemilu Anggota Lembaga Perwakilan ditemukan fakta politik bahwa untuk mendapat dukungan demi keterpilihan sebagai Presiden dan dukungan DPR dalam penyelenggaraan pemerintahan, jika terpilih calon Presiden terpaksa harus melakukan negosiasi dan tawar-menawar (bargaining) politik terlebih dahulu dengan partai politik yang berakibat sangat mempengaruhi jalannya roda pemerintahan di kemudian hari. Negosiasi dan tawar-menawar tersebut pada kenyataannya lebih banyak bersifat taktis dan sesaat daripada bersifat strategis dan jangka panjang, misalnya karena persamaan garis perjuangan partai politik jangka panjang. Oleh karena itu, Presiden pada faktanya menjadi sangat tergantung pada partai-partai politik sehingga dapat mereduksi posisi Presiden dalam menjalankan kekuasaan pemerintahan menurut sistem pemerintahan presidensial. Dengan demikian penyelenggaraan Pilpres harus menghindari terjadinya negosiasi dan tawar-menawar (bargaining) politik yang bersifat taktis demi kepentingan sesaat, sehingga tercipta negosiasi dan koalisi strategis partai politik untuk kepentingan jangka panjang. 
Mahkamah Konstitusi berpendapat bahwa norma pelaksanaan Pilpres yang dilakukan setelah Pemilu Legislatif telah nyata tidak sesuai dengan semangat yang dikandung oleh UUD 1945 dan tidak sesuai dengan makna pemilihan umum yang dimaksud oleh UUD 1945, khususnya dalam Pasal 22E ayat (1) UUD 1945 yang menyatakan, "Pemilihan umum dilaksanakan secara langsung, umum, bebas, rahasia, jujur, dan adil setiap lima tahun sekali" dan Pasal 22E ayat (2) UUD 1945 yang menyatakan, "Pemilihan umum diselenggarakan untuk memilih anggota Dewan Perwakilan Rakyat, Dewan Perwakilan Daerah, Presiden dan Wakil Presiden dan Dewan Perwakilan Rakyat Daerah", serta Pasal 1 ayat (2) UUD 1945 yang menyatakan, "Kedaulatan berada di tangan rakyat dan dilaksanakan menurut UUD".

Sementara itu sebagian masyarakat masih menilai bahwa selama ini Pemilu hanya sebagai agenda rutinitas lima tahunan yang menghabiskan uang rakyat, sementara hasil dari pelaksanaan Pemilu itu sendiri belum mampu menciptakan masyarakat yang adil dan sejahtera. Anggapan seperti ini tentunya menjadi masukan bagi penyelenggara Pemilu untuk lebih baik dalam melaksanakan agenda Pemilu di masa yang akan datang. Dan salah satu proses perbaikan tersebut adalah dengan dibukanya kran penyelesaian sengketa selama berlangsungnya proses Pemilu, sebagai bagian dari penegakan hukum Pemilu.

Sengketa bisa terjadi disetiap tahapan Pemilu sebagaimana dikemukakan oleh Janedjri M. Gaffar yang dikutip oleh Refly Harun bahwa, terjadinya sengketa atau pelanggaran sangat mungkin terjadi di dalam setiap tahapan penyelenggaraan Pemilu. Kemungkinan tersebut bisa disebabkan oleh kecurangan (fraud), kekhilafan (mistake), maupun strategi pemenangan pemilu yang tidak melanggar hukum tetapi menurunkan kepercayaan publik (non-fraudulent misconduct).

Karena penegakan hukum pemilu merupakan salah satu indikator pemilu yang demokratis, maka jika ingin melihat keberhasilan penyelenggaraan pemilu, salah satu ukuran yang paling penting untuk dilihat adalah berjalan atau tidaknya proses penegakan hukum. Artinya, ketika terjadi kecurangan dalam penyelenggaraan pemilu, mekanisme hukum yang telah disediakan berjalan atau tidak. Begitu juga ketika terdapat manipulasi suara maka mekanisme hukum yang berlaku mampu memberikan jalan keluar atau bahkan mengembalikan hak elektoral pemilih seperti sedia kala.(Refly Harun,2016:5).

Fungsi penyelesaian sengketa proses oleh Bawaslu ini menurut Perludem, merupakan fungsi baru Bawaslu yang sesungguhnya lebih menjanjikan, karena keputusan Bawaslu merupakan keputusan terakhir dan mengikat. Sebagaimana 
dalam ketentuan Pasal 259 ayat (1) UU Nomor 8 Tahun 2012 menyatakan, "Keputusan Bawaslu mengenai penyelesaian sengketa Pemilu merupakan keputusan terakhir dan mengikat, kecuali keputusan terhadap sengketa Pemilu yang berkaitan dengan verifikasi Partai Politik Peserta Pemilu dan daftar calon tetap anggota DPR, DPD, DPRD provinsi, dan DPRD kabupaten/kota." Namun sayangnya, Bawaslu terlihat kurang memaksimalkan fungsi ini(Jurnal Konstitusi,2016:5). Maka Perludem juga merekomendasikan agar fungsi penyelesaian sengketa pemilu yang diperkuat; sedangkan fungsi pengawasan dan penanganan pelanggaran direformasi sedemikian rupa agar lebih efektif.

Dan penguatan fungsi penyelesian sengketa oleh Bawaslu ini sudah diakomodir oleh undang-Undang Nomor 7 Tahun 2017, dimana pada Pasal 95 huruf d memberikan wewenang kepada Bawaslu untuk menerima, memeriksa, melakukan mediasi dan adjudikasi serta memutus penyelesaian sengketa pemilu. Artinya berdasarkan UndangUndang Nomor 7 Tahun 2017 dalam melakukan penyelesaian sengketa proses Pemilu, Bawaslu diberikan tambahan kewenangan untuk melakukan mediasi dan adjudikasi.

Hal ini tentu berbeda dengan penyelesaian sengketa proses Pemilu oleh Bawaslu dalam Pemilu 2014, yang tidak menegaskan adanya kewenangan untuk memeriksa sengketa secara adjudikasi. Sehingga penyelesaian sengketa proses Pemilu 2014 itu berjalan secara tidak sistematis dan rancu dari segi hukum acara. Dimana penyelesaian sengketa diawali dengan musyawarah, namun bila tidak mencapai kesepakatan maka Bawaslu akan mengambil/menjatuhkan Putusan, tanpa melalui proses adjudikasi.

Dengan peran dan kewenangan menyelesaikan sengketa melalui proses mediasi dan adjudikasi tentu merupakan suatu hal yang memperkuat fungsi dan peran Bawaslu sebagai lembaga penyelesaian sengketa (khusus untuk sengketa proses Pemilu), karena sengketa hasil Pemilu berdasarkan UndangUndang Nomor 7 Tahun 2017 masih tetap menjadi kewenangan Mahkamah Konstitusi. Hal ini tentu sejogyanya tidak hanya dimaknai sebagai penambahan kewenangan dan penguatan peran, namun yang paling penting tentu adalah kesiapan Bawaslu dalam mengawal penyelesaian sengketa oleh Bawaslu jajarannya sebaik mungkin untuk berhasilnya penegakan hukum Pemilu yang optimal demi tercapainya Pemilu yang demokratis dan berintegritas.

\section{B. Tantangan dan Masa Depan Penyelesaian Sengketa Proses Pemilu oleh Bawaslu}


Bahwa awalnya sengketa proses Pemilu ini hanya merupakan kewenangan Bawaslu RI, sebagaimana diamanatkan oleh Pasal 258 ayat (2) UU Nomor 8 Tahun 2012 yang memberikan hak eksklusif tersebut hanya kepada Bawaslu, yang dalam pelaksanaannya dapat mendelegasikan kepada pengawas di tingkat bawah mulai dari Bawaslu provinsi hingga PPL.

Selanjutnya dalam Peraturan Bawaslu Nomor 15 Tahun 2012, Bawaslu, Bawaslu Provinsi, Panwaslu Kabupaten/Kota, Panwascam, Pengawas Pemilu Lapangan dan Pengawas Pemilu Luar Negeri menyelesaikan sengketa yang timbul karena adanya :

- Perbedaan penafsiran atau suatu ketidakjelasan tertentu yang berkaitan dengan suatu masalah fakta kegiatan, peristiwa, dan/atau ketentuan Peraturan Perundangundangan mengenai Pemilu antar Peserta Pemilu;

- Keadaan dimana pengakuan atau pendapat dari salah satu Peserta Pemilu mendapatkan penolakan, pengakuan yang berbeda, dan/atau penghindaran dari Peserta Pemilu yang lain;

- Keputusan KPU/KIP, KPU/KIP Provinsi dan KPU/KIP Kabupaten/Kota.

Jadi bila dirunut dari mulainya Bawaslu melakoni peran sebagai lembaga penyelesaian sengketa yaitu dalam Pemilu 2014 yang lalu, tentu saja sudah jauh perubahan dari sisi kewenangan yang diamanatkan kepada bawaslu dalam menyelesaikan sengketa proses Pemilu ini. Dimana dalam penyelesaian sengketa proses Pemilu yaitunya sengketa penetapan partai politik peserta Pemilu oleh KPU serta sengketa tentang penetapan Daftar Calon Sementara Pemilu Legislatif oleh KPU penyelesaian sengketa dilakukan oleh Bawaslu dengan melalui proses mediasi, dan bilamana tidak tercapai kesepakatan maka proses dilanjutkan dengan layaknya proses adjudikasi yaitu dengan pemeriksaan surat dan saksi. Namun pada tahap penyelesaian sengketa Daftar Calon Tetap (DCT) Pemilu Legislatif oleh KPU penyelesaian sengketa dilakukan oleh Bawaslu tidak lagi melalui tahapan adjudikasi. Semua proses dilalui dengan layaknya tahapan mediasi. Demikian juga layout pemeriksaan, tidak layaknya layout persidangan. Namun akhir dari proses mediasi yang tidak mencapai kesepakatan ditutup dengan Putusan Bawaslu. Hal ini tentu rancu dan menyimpang dari hukum acara persidangan.

Selanjutnya dalam penyelesaian sengketa proses Pemilu 2014, sengketa DCS dan DCT Provinsi dan DCS serta DCT Kabupaten/Kota diselesaikan oleh Bawaslu Provinsi. Maka bilamana dalam Undang-Undang Nomor 8 Tahun 2012 dan Undang Undang Nomor 15 Tahun 2011 sengketa proses pemilu 
hanya dapat diselesaikan oleh Badan Pengawas Pemilu (Bawaslu) RI, maka kini dengan Undang Undang Nomor 7 Tahun 2017, sengketa proses dapat ditindak oleh Bawaslu provinsi dan Bawaslu kabupaten/kota. Peserta pemilu dapat mengajukan sengketa proses tiga hari sejak keluarnya keputusan KPU dan Bawaslu wajib menyelesaikan sengketa dalam waktu 14 hari.

Putusan Bawaslu terhadap sengketa proses bersifat final, kecuali untuk tiga hal, yakni bila berkaitan dengan verifikasi calon partai politik peserta pemilu, penetapan calon anggota DPR, DPD, DPRD provinsi dan DPRD kabupaten/kota, dan penetapan calon. Partai politik dapat mengajukan banding ke Pengadilan Tata Usaha Negara (PTUN). Hal tentu juga merupakan penguatan peran dan kewenangan yang tidak main-main bagi Bawaslu dan jajarannya.

Hasil putusan sengketa yang bersifat final dan mengikat, menjadikan Bawaslu sangat diharapkan masyarakat dalam menyelesaikan sengketa yang kerap terjadi saat tahapan Pemilu. Hingga dengan demikian penyelesaian sengketa bagi Bawaslu adalah mahkota yang keberadaannya dinanti oleh masyarakat. Namun mahkota-nya Bawaslu ini akan meredup sinarnya bilamana dalam menjalankan peran sebagai hakimnya Pemilu Bawaslu tidak mampu menampilkan putusan yang objektif, dan bisa diterima oleh semua pihak yang bertikai. Hal ini tentu menjadi tantangan besar bagi Bawaslu kedepan, bagaimana bisa menjadikan mahkotanya ini semakin berkilau, dipercayai masyarakat dan mampu menciptakan Pemilu yang bersih dan demokratis yang dicita-citakan.

Penyelesaian sengketa Pemilu ini mempunyai fungsi strategis dalam kerangka sistem Pemilu. Salah satu indikator Pemilu itu sukses atau tidak. Bila dikaitkan dengan hasil penyelesaian sengketa yang dilakukan oleh Bawaslu selama ini, dimana mengedepankan keadilan substantif dalam putusanputusanya. Maka ini jua menjadi tantangan terbesar bagi Bawaslu. Karena keadilan substantif yang hendak digapai tersebut bukanlah perkara mudah.

Sebagaimana dikemukakan oleh Saldi Isra bahwa dalam batas-batas tertentu, ruang subjektivitas yang seharusnya dapat digunakan untuk mewujudkan keadilan substantif acap kali bergerak liar di luar tujuan penegakan hukum. Ruang subjektivitas bagaikan pisau bermata dua. Pada satu sisi ia dapat digerakkan ke arah mewujudkan keadilan substanstif di dalam penegakan hukum, tetapi di sisi lain membuka kesempatan untuk terjadinya penyimpangan.( Saldi Isra,2016). Lebih lanjut Saldi Isra mengemukakan bahwa ruang subjektif untuk mewujudkan keadilan hanya dapat dilakukan penegak hukum yang profesional dan amanah. Sebaliknya, ruang itu 
akandisalahgunakan jika penegak hukum diisi kalangan yang tidak profesional dan tidak menjaga integritas.

Hal ini tantangan bagi Bawaslu kedepan bagaimana menjaga amanah yang diamanatkan kepada Bawaslu sebagai penjaga keadilan Pemilu. Bagaimana memastikan bahwa semua jajaran Bawaslu memegang teguh integritasnya dalam menyelesaikan sengketa Pemilu. Dan menjadi tantangan juga bagi Bawaslu untuk menjawab keraguan sebagian pihak bahwa ada Kemungkinan penyalahgunaan wewenang akan lebih besar apabila hanya ada satu lembaga otoritas yang ditunjuk untuk menyelenggarakan pemilu sekaligus menyelesaikan sengketa yang muncul dalam pemilu, dalam hal ini badan penyelenggara pemilu bertindak sebagai hakim dan pihak yang disengketakan untuk kasus yang sama.(International IDEA,2010). sebagaimana yang dilakoni oleh Bawaslu saat ini sebagai penyelenggara Pemilu, yang bertugas mengawasi Pemilu, sekaligus juga sebagai sebagai lembaga yang menyelesaikan sengketa Pemilu. Walau sesungguhnya keberadaan Bawaslu yang mengawasi pelaksanaan pemilu sudah tidak relevan dengan perkembangan pemilu masa kini. Sebab fungsi pengawasan kini bisa dialihkan kepada masyarakat sipil. Dan oleh karenanya, Bawaslu kedepan bisa didesain menjadi Pengadilan Pemilu.

Untuk mewujudkan tantangan ini maka Bawaslu harus semakin menyiapkan infrastruktur untuk menjaga efektifitas penyelesaian sengketa serta penguatan kapasitas Bawaslu di tingkat provinsi, kabupaten/kota sebagai fungsi mediator dan adjudikator. Mengingat penyelesaian sengketa proses Pemilu yang dilakukan oleh Bawaslu adalah dalam upaya menyelesaikan konflik horizontal, yang rawan untuk disertai dengan kekerasan. Dimana bila konflik dan kekerasan ini terlambat atau salah dalam penangannya akan dapat melemahkan persatuan bangsa dan menghambat pembangunan nasional, karena konflik bermuara dari perbedaan yang bersumber dari kemajemukan.

Menjadi tantangan tersendiri bagi Bawaslu untuk membuktikan bahwa Bawaslu mampu menjalankan peran sebagai mediator dan adjudikator sebagaimana kewenangan yang sudah diamanatkan oleh undang-undang Pemilu demi legitimasi dalam menyelesaikan konflik hukum. Bawaslu harus mampu menjawab kekhawatiran bahwa lembaga peradilan oleh Bawaslu kurang mempunyai kapasitas dan kredibilitas dalam menyelesaikan sengketa dalam proses atau tahapan pemilu. Menjawab dan membuktikan tantangan ini tentu tidaklah mudah. Dan salah satu syarat yang untuk bisa menjawab tantangan ini adalah dengan cara Bawaslu, Bawaslu Provinsi dan Bawaslu Kabupaten/Kota haruslah diisi oleh orang-orang yang memiliki latar belakang keilmuan di bidang 
pemilu dan hukum pemilu. Hingga tidak ada lagi putusan penyelesaian sengketa proses Pemilu yang justru menciptakan masalah baru dalam tahapan Pemilu.

Namun karena Bawaslu di daerah juga sudah terpilih, dan banyak diantaranya yang justru tidak berlatar belakang sarjana hukum, sehingga tidak memiliki pengalaman di persidangan. Untuk itu tentu Bawaslu perlu untuk lebih menggiatkan pelatihan buat jajarannya agar sukses memainkan peran sebagai mediator dan adjudikator. Terutama jajaran Bawaslu ditingkat Kabupaten/Kota yang sebagian besar tidak mempunyai latar belakang pendidikan di bidang pemilu dan hukum pemilu untuk betul-betul memahami perbedaan mediasi dengan adjudikasi, serta mampu menjatuhkan putusan yang memuat nilai-nilai keadilan dan bisa dipertanggungjawabkan. Sebagaimana diakui oleh Bawaslu RI bahwa Bawaslu harus melatih kemampuan serta mental Bawaslu di daerah yang masih rendah untuk menyelesaikan sengketa pemilu.

Dan jajaran Bawaslu Provinsi serta Bawaslu Kabupaten/Kota yang juga diamanatkan dalam penyelesaian sengketa perlu mengoptimalkan proses pembelajaran untuk meningkatkan kemampuannya dalam menyelesaikan proses sengketa di daerah masing-masing Hingga Bawaslu sebagai Pengadilan Pemilu suatu saat bisa menjadi aktual. Dan Bawaslu bisa menjadi peran penentu dalam keberhasilan Pemilu Indonesia

\section{PENUTUP}

Penyelesaian sengketa Pemilu merupakan bagian dari penegakan hukum Pemilu. Undang-Undang Pemilu Nomor 7 Tahun 2017 telah memberi peran kepada Bawaslu dan jajarannya sebagai mediator dan adjudikator demi legitimasi dalam menyelesaikan konflik hukum sepanjang proses Pemilu. Tujuan akhir yang hendak dicapai dari penambahan kewenangan penyelesaian sengketa ini adalah menjadikan Bawaslu sebagai cikal bakal Pengadilan Pemilu. Ini tentu tantangan tersendiri bagi Bawaslu untuk menjawab keraguan beberapa pihak akan kemampuan Bawaslu memainkan peran penyelesaian sengketa yang justru menjadi mahkota bagi Bawaslu. Dan untuk mewujudkan tantangan ini maka Bawaslu harus semakin menyiapkan infrastruktur untuk menjaga efektifitas penyelesaian sengketa serta penguatan kapasitas Bawaslu di tingkat provinsi, kabupaten/kota sekaligus sebagai fungsi mediator dan adjudikator. 
Penyelesaian Sengketa Proses Pemilu Oleh Bawaslu, Tantangan Dan Masa Depan (Aermadepa)

\section{Daftar Bacaan}

Dahlan Thaib, (1993), Implementasi Sistem Ketatanegaraan Menurut UUD 1945, Yogyakarta : Liberty,

Didik Sukriono, (2009), Menggagas Sistem Pemilihan Umum, Jurnal Konstitusi PKK Universitas Kanjuruhan Malang Volume II Nomor 1, Juni

Jimly Asshiddiqie, (1994), Gagasan Kedaulatan Rakyat dalam Konstitusi dan Pelaksaannya di Indonesia Pergeseran Keseimbangan Antara Individualisme dan Kolektivitisme dalam Kebijakan Demokrasi Politik dan Demokrasi Ekonomi Selama Tiga Masa Demokrasi, 1945-1980-an, Jakarta : PT Ichtiar Baru Van Hoeve.

\section{Grafika.} (2010). Konstitusi dan Konstitusionalisme, Jakarta: Sinar

Kemitraan, (2011), Penanganan Sengketa Pemilu, Buku 16, Jakarta : Kemitraan bagi Pembaruan Tata Pemerintahan.

Ramlan Surbakti, dkk, (2008), Perekayasaan Sistem Pemilu untuk Pembangunan Tata Politik Demokratis, Cet I, Jakarta: Kemitraan.

Refly Harun, Rekonstruksi Kewenangan Penyelesaian Perselisihan Hasil Pemilihan Umum, Jurnal Konstitusi, Volume 13, Nomor 1, Maret 2016.

Sri Soemantri M, (1998), Perngantar Perbandingan Hukum Tata Negara, Jakarta : Rajawali Pers.

Takdir Rahmadi, (2011), Mediasi Penyelesaian Sengketa Melalui Pendekatan Mufakat, Jakarta : Rajawali Pers.

Topo Santoso, dkk, (2006), Penegakan Hukum Pemilu Praktik Pemilu 2004, Kajian Pemilu 2009-2014, Jakarta : Perludem.

Veri Junaidi, dkk, (2015), Evaluasi Penegakan Hukum Pemilu 2014, Jakarta : Yayasan Perludem.

Winardi, (2007), Managemen Konflik (Konflik Perubahan dan Pengembangan), Bandung : Mandar Maju.

International IDEA, (2010), Keadilan Pemilu: Ringkasan Buku AcuanInternational IDEA,https://www.idea.int/sites/default/files/publications/electoraljustice-handbook-overview-ID.pdf, diakses tanggal 22 September 2018.

Mohammad Dawam, Prospek Penanganan Sengketa Pemilu 2019, https:/ / Komisi\%20Informasi\%20-\%20PROSPEK\%20PENANGANAN\% 20SENGKETA \%20PEMILU\%202019.html, diakses pada tanggal 22 Septembr 2018.

Penyelesaian Sengketa Pemilu di Daerah Belum Maksimal, http:/ /www.teropongsenayan.com/81715-penyelesaian-sengketapemilu-di-daerah-belum-maksimal, diakses pada tanggal 22 September 2018.

Saldi Isra, (2016), Memastikan Pembaruan Hukum, Media Online Gagasan Hukum, https://gagasanhukum.wordpress.com/tag/saldi-isra/, diakses tanggal 20 September 2018 